\title{
Development and organization of the lamprey telencephalon with special reference to the GABAergic system
}

\section{Manuel A. Pombal*, Rosa Álvarez-Otero, Juan Pérez-Fernández, Cristina Solveira and Manuel Megías}

Neurolam Group, Department of Functional Biology and Health Sciences, Faculty of Biology, University of Vigo, Vigo, Spain

\section{Edited by:}

Agustín González, Universidad Complutense de Madrid, Spain

Reviewed by:

Nerea Moreno, University

Complutense of Madrid, Spain

Sylvie Retaux, Centre National de la

Recherche Scientifique, France

${ }^{*}$ Correspondence:

Manuel A. Pombal, Neurolam Group, Department of Functional Biology and Health Sciences, Faculty of Biology, University of Vigo, 36310 Vigo, Spain. e-mail:pombal@uvigo.es
Lampreys, together with hagfishes, represent the sister group of gnathostome vertebrates. There is an increasing interest for comparing the forebrain organization observed in lampreys and gnathostomes to shed light on vertebrate brain evolution. Within the prosencephalon, there is now a general agreement on the major subdivisions of the lamprey diencephalon; however, the organization of the telencephalon, and particularly its pallial subdivisions, is still a matter of controversy. In this study, recent progress on the development and organization of the lamprey telencephalon is reviewed, with particular emphasis on the GABA immunoreactive cell populations trying to understand their putative origin. First, we describe some early general cytoarchitectonic events by searching the classical literature as well as our collection of embryonic and prolarval series of hematoxylin-stained sections. Then, we comment on the cell proliferation activity throughout the larval period, followed by a detailed description of the early events on the development of the telencephalic GABAergic system. In this context, lampreys apparently do not possess the same molecularly distinct subdivisions of the gnathostome basal telencephalon because of the absence of a $N k \times 2.1$-expressing domain in the developing subpallium; a fact that has been related to the absence of a medial ganglionic eminence as well as of its derived nucleus in gnathostomes, the pallidum. Therefore, these data raise interesting questions such as whether or not a different mechanism to specify telencephalic GABAergic neurons exists in lampreys or what are their migration pathways. Finally, we summarize the organization of the adult lamprey telencephalon by analyzing the main proposed conceptions, including the available data on the expression pattern of some developmental regulatory genes which are of importance for building its adult shape.

Keywords: pallium, subpallium, cell proliferation, evolution, olfactory bulbs, preoptic region, agnathans, cyclostomes

\section{INTRODUCTION}

The lamprey is an interesting animal model due to the position that occupies in the phylogeny, being considered, together with myxines, the sister out-group of the gnathostomes. Many outstanding developmental studies on the lamprey were carried out by the end of the ninetieth and the beginning of the twentieth centuries (reviewed in Nieuwenhuys and Nicholson, 1998; Richardson and Wright, 2003; Richardson et al., 2010). Some of them described in detail the early developmental stages of its central nervous system (CNS). At the time, a number of valuable accounts also addressed the organization of the adult lamprey brain (reviewed in Nieuwenhuys and Nicholson, 1998; Pombal et al., 2009). In the last two decades, there is a growing interest in the molecular genetics of these animals because of their phylogenetic position (reviewed in Kuratani et al., 2002; Murakami et al., 2005; Osório and Rétaux, 2008; Murakami and Watanabe, 2009; Nikitina et al., 2009), as well as on the cytoarchitectonic, chemical, and hodological characterization of their CNS (reviewed in Nieuwenhuys and Nicholson, 1998; Pombal and Puelles, 1999; Weigle and Northcutt, 1999; Osório and Rétaux, 2008; Pombal and Megías, in press). In this paper, we provide an overview and literature survey on the earliest development of the lamprey telencephalon, including some additional information from our own collection of paraffin and semithin serial sections of different developmental stages (including embryonic, prolarvae, larvae, postmetamorphic, and adult animals). In addition, we review the existing data concerning cell proliferation on the lamprey brain with special emphasis on the GABAergic system and add some new data from our experimental material.

Lampreys have a very small brain, as compared with most gnathostomes, and their telencephalon, in particular, is very tiny. The telencephalic hemispheres arise as an unpaired and solid rudiment, which later divides into two portions (Scott, 1887). After hatching, as it occurs for the rest of the brain, they develop slowly throughout the prolarval and larval stages, which can last more than 5 years due to the extremely long larval period of these animals (reviewed in Hardisty and Potter, 1971). Then, the whole brain suffers a dramatic transformation during metamorphosis and practically doubles its size (Healey, 1972). The shape of the brain do not change so much through the adult period, but continues increasing in size.

\section{STAGING AND LAMPREY DEVELOPMENT}

In our laboratory, sea lamprey (Petromyzon marinus) embryos and prolarvae are grown from in vitro fertilized eggs. Sexual mature adult animals of both sexes were handnetted directly from their nests in tributaries of Miño River (NW of Spain) during the breeding season (from May to July). After collection, they are transported to the laboratory to perform the fertilization. Then, the eggs are reared in polypropylene tanks with a circulating water system under 
appropriate conditions of darkness and temperature $\left(18 \pm 0.5^{\circ} \mathrm{C}\right.$; Piavis, 1961, 1971). Under these conditions hatching occurs at 10-13 days post-fertilization ( $\mathrm{dpf}$ ).

The most common used staging series of early development for the sea lamprey is that of Piavis $(1961,1971)$. In his studies, Piavis subdivided the early development into 19 stages, from the ovulated but unfertilized egg to the first stage of larva (or ammocoete), which occurs approximately at 33-40 dpf. Therefore, we will follow this classification by indicating the relative stage (from P10 to P18, where $\mathrm{P}$ refers to Piavis), and referring to the age of the animal as days after fertilization (from 4 to $33 \mathrm{dpf}$ ) or to the length in millimeters, when known. Although in several recent works the different stages of this developmental period are considered as embryonic, we consider that only those until hatching should be referred to as embryonic, whereas those from hatching to the onset of filter feeding should be regarded as prolarvae. Moreover, as the age of larvae collected in the river is unknown, we will use their total body length in millimeters as reference.

As commented above, there are in the "old" literature a number of high quality reports on lamprey development focusing on the CNS. However, a direct comparison of these reports is sometimes difficult because of variations between species ( $P$. marinus, L. fluviatilis, and L. japonica are the most common species in the literature; see review by Richardson et al., 2010), and/or between the experimental conditions used in each case to raise the animals. An illustrative example concerns the temperature, which can dramatically affects the survival rate and the growth during the early stages of development (Piavis, 1961; Rodríguez-Muñoz et al., 2001). Therefore, the time to hatch and body length of the hatching prolarva can vary in relation to the temperature of incubation of the fertilize eggs (when known): P. marinus (hatching at 11-13 dpf and 3-5 mm in size at $18.4^{\circ} \mathrm{C}$; Piavis, 1961, 1971), L. tridentata, Pacific lamprey and L. richardsoni, western brook lamprey (hatching at $15 \mathrm{dpf}$ and about $4.5 \mathrm{~mm}$ in size at $14^{\circ} \mathrm{C}$; Meeuwig et al., 2006), and $L$. reissneri (hatching at 11-12 dpf and up to $4 \mathrm{~mm}$ body length at $16^{\circ} \mathrm{C}$; Tahara, 1988).

\section{EARLY DEVELOPMENT OF THE CNS}

The CNS of all chordates develops from the neural plate, a thickened and elongated paramedian zone of the ectoderm, which in lampreys is first seen at about $4.5 \mathrm{dpf}$ (Shipley, 1887; von Kupffer, 1906). Then the edges of the neural plate fuse to form a solid cord of neuroectoderm [a neural rod as described by Damas (1944), and Shipley, (1887)], which cavitates to form a hollow neural tube when neurulation has been completed (reviewed in Nieuwenhuys and Nicholson, 1998; Osório and Rétaux, 2008). Initially, the lateral walls of the neural tube consist of a pseudostratified epithelium of elongated cells that soon widens to form a thicker ventricular matrix layer (stratified epithelium), with the first neuroblasts appearing at its external border before hatching. At these earliest stages of development, the cells are filled with yolk platelets (Damas, 1944; Scott, 1887; Shipley, 1887; reviewed in Richardson et al., 2010).

According to Ahlborn (1883), two portions can be distinguished in the lamprey neural tube soon after fecundation (4-5 dpf, P10; Sterzi, 1907): prechordal and chordal (epichordal), which correspond to the archencephalon and deuterencephalon of von Kupffer (1906), respectively; however, the exact rostral ending of the notochord has clearly been unresolved for a long time and the possibility that the entire neural tube is epichordal has been recently proposed (see Pombal et al., 2009). At this stage, the lateral walls consist of a stratum of few cells in thickness whereas the dorsal (roof) and ventral (floor) midlines are formed by a single cell layer epithelium of elongated cells (Sterzi, 1907; Damas, 1944). The nasal epithelium starts its differentiation in a relatively ventral position at this stage, when the cranial flexure attains its maximum (Scott, 1887; Shipley, 1887 ); shortly after, an ingrowth of ectodermic cells represents the primordium of the nasohypophyseal duct and sac (Figure 1). With development, however, the primordium of the olfactory epithelium shifts toward anterior, with the nasal opening (a single and medial small pore) finally arriving to a dorsal position in the top of the head of late prolarvae (about $8 \mathrm{~mm}$ length, 26-29 dpf, P17 stage; Figure 1D; reviewed in Kuratani et al., 2001; Richardson et al., 2010). This shifting of the olfactory apparatus is conditioned by the enlargement of the upper lip (reviewed in Kuratani et al., 2001; see also their Figures 6 and 10), and by the correction of the cephalic flexure due to a partial rotation of the rostral neural tube (Scott, 1887; Sterzi, 1907; Källén, 1951). It is noteworthy that this rotation implies a simultaneous and remarkable topographical rotation of the most rostral nuclei and regions of the forebrain (rostral to the pretectum), which should be taken into account when interpreting experimental results at these developmental stages.

By the stage P12 (7-8 dpf, 3 mm length), the rostralmost portion of the neural tube that corresponds to the primordium of the evaginated portion of the telencephalon bulges out laterally (i.e., it begins to enlarge and thicken), and a dorsal evagination (the rudiment of the pineal vesicle) also appears in the dorsal midline (Scott, 1887; Shipley, 1887; von Kupffer, 1906; Sterzi, 1907; reviewed in Meléndez-Ferro et al., 2002b; Villar-Cheda et al., 2002). At Piavis developmental stage 13 (P13, prehatching), two diverticula are giving off, which constitute the primordial of the optic stalk and the optic vesicle (Figure 2A), and immediately after (4 mm embryo), the optic chiasma is observable at the rostral midline (Shipley, 1887; von Kupffer, 1906; Sterzi, 1907; Damas, 1944; see Figure 2E). At this level, an increasing number of fibers subsequently cross the midline to originate a conspicuous postoptic commissure (Figure 2C), which can be later subdivided into dorsal and ventral postoptic commissures (Pombal and Puelles, 1999).

At hatching (P14; 10-13 dpf), the lamprey brain is somehow poorly developed, and its lateral walls are thin and mostly formed by spindle shaped cells. According to von Kupffer (1906), it is in this stage when a sulcus intraencephalicus anterior is identified for the first time running dorsoventrally from the vicinity of the habenular commissure down to the preoptic recess (Figures 2A-D). Later, Sterzi (1907) made a graphical reconstruction of this sulcus in the $9,16.5$, and $35 \mathrm{~mm}$ stages, which, until nowadays, has been commonly used in the literature as a reference for the boundary between the telencephalon and the diencephalon (Nieuwenhuys and Nicholson, 1998; Meléndez-Ferro et al., 2002a; Villar-Cheda et al., 2006). The ontogeny of this and other prosencephalic sulci as well as their interpretation by different workers was addressed in detail by Källén (1951).

After hatching, the number of cells increase and the walls of the brain become thicker, with the first fibers appearing in its ventrolateral margins (Figure 2B). In addition, some migrating cells start to 


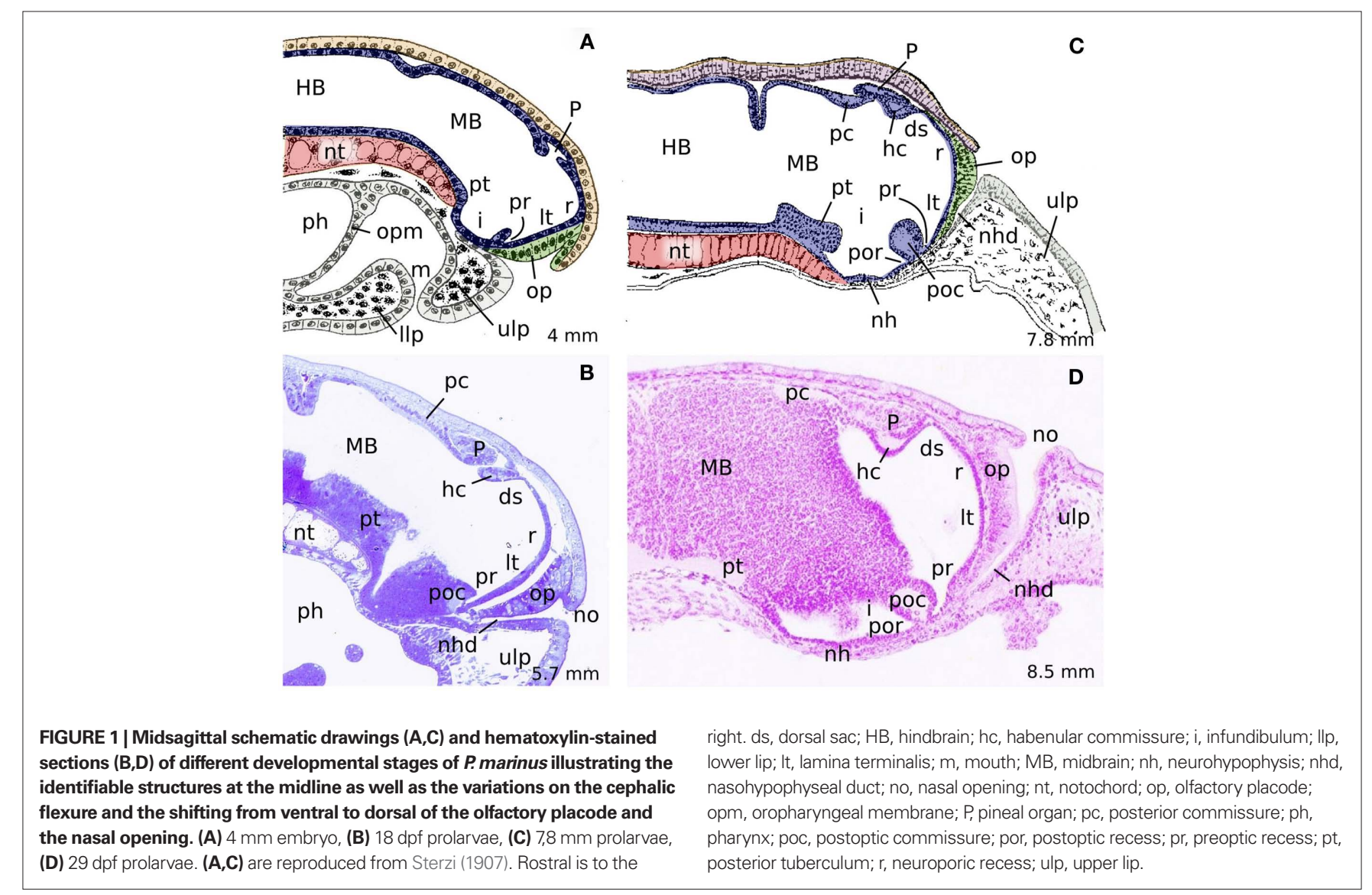

colonize the primordium of the cerebral hemispheres. At this stage (which corresponds to P15 stage), the olfactory bulbs are no yet differentiated (Scott, 1887), and were first identified by Bergquist and Källén (1953) in a 12-mm larva; they are, at first, smaller than the telencephalic hemispheres, but grow considerably, probably due to the conspicuous increasing in size and complexity of the olfactory apparatus during metamorphosis, to become larger in the adult (Scott, 1887; VanDenbossche et al., 1995; Pombal et al., 2002; reviewed in Kleerekoper, 1982; Ren et al., 2009). Although Scott (1887) and Shipley (1887) were not able to observe any trace of the lateral ventricles in late prolarvae, in our material the anlage of the hemispheric evagination (foramen interventricular) is already detected around day 32 after fertilization [P17; Figure 2F; $7.5 \mathrm{~mm}$ stage for Bergquist (1952), and Källén (1951) or $7.8 \mathrm{~mm}$ larva according to Sterzi (1907)].

At the rostral end of the neural tube, the walls of the telencephalon impar are connected by the lamina terminalis (Figures 1 and 2D-F), which is slowly widened ventrally to form the bed of the anterior commissure (commissure of the lamina terminalis of Pombal and Puelles, 1999). The lamina terminalis continues dorsally with the rostralmost portion of the roof plate represented by the neuroporic recess (Figure 1). This recess is followed by the telencephalic commissural plate, which is mostly formed by the interbulbar (dorsal or pallial) commissure; this commissure was recently interpreted as the homolog of the septal commissural plate of gnathostomes, and might include a primordium of the anterior commissure and of a hippocampal commissure at its rostral and caudal ends, respectively (Pombal et al., 2009). Of note, both the commissure of the lamina terminalis and the interbulbar commissure are not yet distinguished in late prolarvae (see Figures $\mathbf{1}$ and 2E). From small larvae (16.5 $\mathrm{mm}$ for Sterzi, 1907), the interbulbar commissure increases considerably in size throughout development. Though it was represented in schematic drawings of prolarval lampreys by different authors (Burckhardt, 1894; von Kupffer, 1906; see also Figure 1C from Sterzi, 1907), the commissure of the lamina terminalis, however, cannot be readily identified until after midlarval stages (Scott, 1887). This commissure is also tiny and poorly developed in adult specimens, even in the anadromous $P$. marinus that have the largest brain, where it is formed by a thin commissural lamina that is undoubtedly distinguished only when some of the few fibers crossing through it are specifically labeled (Pombal and Puelles, 1999).

The telencephalic commissural plate continues with a choroidal epithelium constituted by a rostral part (lamina supraneuroporica) and a caudal part (dorsal choroid sac) separated by an inward velum transversum fold (von Kupffer, 1906; Sterzi, 1907; Johnston, 1912; see also Pombal et al., 2009). These structures continue caudally with the epithalamic roof area consisting of the highly asymmetric habenula with a thick habenular commissure and the pineal and parapineal complex (Figures 1 and 2B,C,E). Immediately caudal to a small recess of the third ventricle, the pineal recess, there appears the thickest commissure of the prosencephalic roof plate, the posterior commissure (Figures 1 and 2E). This last commissure is, in fact, the first to appear during development [around $16 \mathrm{dpf}$ prolarvae 


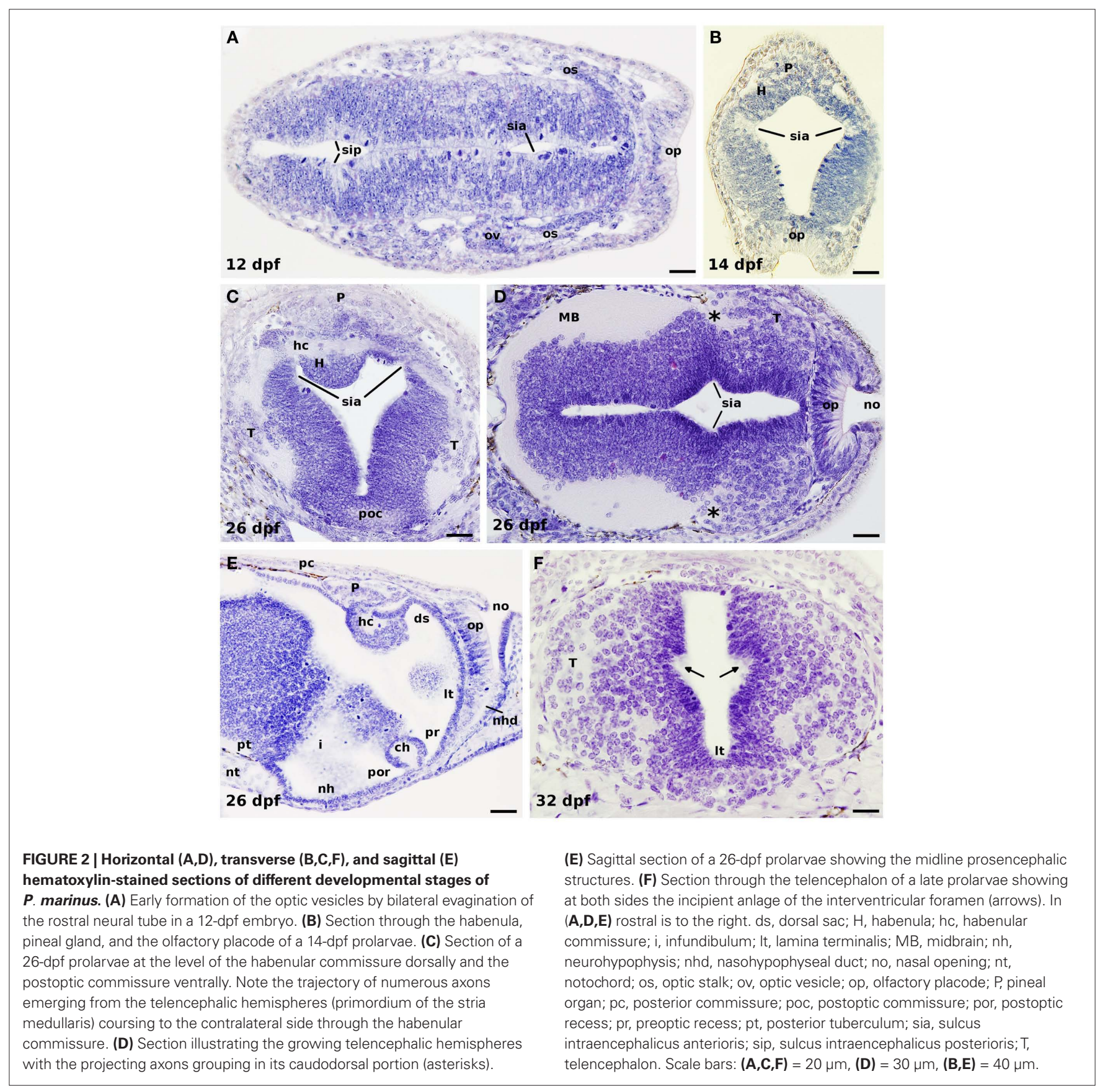

or P15; 4 mm length for von Kupffer (1906), $4.5 \mathrm{~mm}$ for Damas (1944), and $5 \mathrm{~mm}$ length for Sterzi (1907); see Figures 1 and 2E], whereas the primordium of the superior (habenular) commissure is distinguished somehow later [about $18 \mathrm{dpf}$; see Figures 1 and 2C,E; $23 \mathrm{dpf}$ for Shipley (1887), and $5 \mathrm{~mm}$ length for Sterzi (1907), but earlier (4 mm length) for Damas (1944)]. Lampreys also possess a relatively conspicuous postoptic commissure that is first observed at P15 (about 13-15 dpf). A remarkable number of telencephalic contralateral projections, however, cross through the habenular (superior) commissure (Polenova and Vesselkin, 1993; Yáñez and Anadón, 1994; Northcutt and Wicht, 1997). Curiously enough, the first projecting axons of the primordial telencephalic hemispheres joint together in its dorsocaudal portion, in a topographical location immediately rostral to the habenular commissure, as observed in transverse sections of late prolarvae (Figure 2C). This is because the extremely large portion of neural tube located between them in adult animals, i.e., the prethalamic eminence of Pombal et al., (2009), is underdeveloped at these early stages (Bergquist and Källén, 1953; see below). Therefore, at this stage of development, the proximity of the habenular commissure to the telencephalic hemispheres could account for the developing projecting fibers to cross the midline through it. In fact, Shipley (1887), as well as Damas (1944), was of opinion that the superior (habenular) commissure is the first to be recognized in the dorsal midline, just before 
differentiation of the habenula: "The first transverse commissure to appear is situated just in front of the stalk of the pineal gland. It forms the superior commissure of Osborn. Afterwards the ganglion cells thicken round it and form the asymmetrical ganglia habenulae." (Shipley, 1887, p. 368).

\section{OF CELL PROLIFERATION AND DEVELOPMENT}

In the first stages of development there is a remarkable enlargement of the neural tube, and numerous mitotic figures can be readily detected by simple searching of paraffin sections treated with a general staining such as hematoxylin (see Figure 2). They are observed exclusively in the proximity of the ventricular surface intermingled with the ependymal and subependymal cells, where they become spherical before division (von Kupffer, 1906; Damas, 1944; Pfister, 1971a; reviewed in Nieuwenhuys and Nicholson, 1998; Villar-Cheda et al., 2006). Afterward, the development of the lamprey brain is a very long process with slow histological differentiation (Schultze, 1856), mainly due to the extremely long larval period (more than 5 years for $P$. marinus) of these animals. In this connection, it may be significant that the same occurs for the body of the larva, which gradually increases in length from around $5 \mathrm{~mm}$ at hatching up to $180 \mathrm{~mm}$ before metamorphosis, though there is an astonishing variation in growth rates (reviewed in Hardisty and Potter, 1971). During the transformation from ammocoete to adult, a period of only a few months, there is an initial increase of proliferating cell nuclear antigen (PCNA)-labeling that disappears progressively in late metamorphic stages (Villar-Cheda et al., 2006); during this period, however, in $P$. marinus there is a remarkable increase of the brain size that nearly doubles its width and height (see Healey, 1972), most likely as a consequence of the enlargement of preexisting neurons, glial cells, and their processes, as suggested by Rovainen (1982). In anadromous lampreys, the brain continues enlarging during the parasitic period to reach the final size in adult breeding animals. According with the studies of Villar-Cheda et al. (2006), no PCNA-ir cells were observed in young postmetamorphic animals, and only a few were present in the habenula of adult, sexually mature specimens. Therefore, these data suggest that the brain growth during this last period of its life cycle is also mostly due to an increase in size of existing nervous cells. Contrary to this, it has been shown that, at least, in the spinal cord of $P$. marinus there is an increase in the number of GABAergic cells from postmetamorphic animals to adults (Ruiz et al., 2004).

Neurogenesis is a common feature of vertebrate CNS, but the rate and places of neuron generation vary between species and depend on the stage of developmental (see Ruiz et al., 2004, and references herein). In 2004 it was pointed out, however, that 5'-bromo-2-deoxyuridine (BrdU)-labeled new generated cells in the lamprey rhombencephalon and spinal cord are not neurons but glial cells (Vidal-Pizarro et al., 2004). Several technical reasons may explain this apparent discrepancy: by one hand, the number of BrdU-labeled cells obtained by these authors appears to be rather low compared with those obtained by Villar-Cheda et al. (2006) and ourselves (present results), which may be due to differences in the efficiency of the protocols employed (exposition to BrdU versus injection of $20 \mu \mathrm{l} / \mathrm{g}$ of body weight of $10 \mathrm{mM}$ BrdU into the body cavity posterior to the last gill); on the other hand, almost all the BrdU-labeled cells described by Vidal-Pizarro et al. (2004; their Figure 9) are located periventricularly and, therefore, may not yet started (or are just starting) the differentiation processes (see also Villar-Cheda et al., 2006), which may preclude labeling with neuronal markers. Moreover, the LCM-3 antibody (a lamprey NF-specific monoclonal antibody), used as specific neuronal marker, does not seems to label most of the neuronal cell bodies in the gray matter spinal cord (see their Figures 10A,D where only two dorsal cells are weakly labeled with this marker). In addition, there are several reports using different technical approaches that clearly support neurogenesis in several parts of the lamprey brain (see for example: Pombal et al., 1994; Rodicio et al., 1995; MeléndezFerro et al., 2002a; Ruiz et al., 2004; Villar-Cerviño et al., 2008, 2009). Furthermore, several genes involved in neurogenesis (Ngn1, NeuroD2, and Id2/3), and regionalization and patterning (LIMkinase 2 and several Sox genes) where reported to be expressed in late embryos and early prolarvae (Guérin et al., 2009).

In the literature, there are several experimental studies reporting cell proliferation during lamprey forebrain development, which include the analysis of two markers: PCNA (Meléndez-Ferro et al., 2002a,b; Villar-Cheda et al., 2002), and BrdU (Tobet et al., 1996; Álvarez-Otero et al., 2002; Vidal-Pizarro et al., 2004; Villar-Cheda et al., 2006; reviewed in Osório and Rétaux, 2008). From these studies it was concluded that the presence of proliferation discontinuities in the ventricular zone of PCNA-labeled sections could be interpreted as putative neuroanatomical limits throughout the lamprey brain (Villar-Cheda et al., 2006); this proliferating marker is, therefore, of help to study and compare the evolution of the nuclear organization and topographical extension of different neuronal entities in the developing brain. In addition, these authors also stressed that the cell cycle in lampreys is very long, and this feature was considered the reason why the nervous system grows slowly throughout the extremely long larval period. Very recently, the expression pattern of a number of genes involved in the control of proliferation, neurogenesis, regionalization, and cell signaling in the forebrain of gnathostomes was also reported in lampreys (Guérin et al., 2009), part of which appears to participate in the morphogenesis of the telencephalon.

In our laboratory, short incubation times (4 days) with BrdU of larvae of different body length revealed a number of labeled cells in a periventricular position (Figures $3 A, B, D, E$ ). In addition, differences are observed between particular ventricular zones in terms of proliferation; so that, in general, the proliferation is higher in some of them such as in the subpallium, being more prominent in the proximities of the lamina terminalis and close to the preoptic recess. At the dorsomedial level, there is a particularly strong proliferation activity in the primordium of the prethalamic eminence (the classical medial pallium) of the different larval sizes analyzed (Figures 3D,E). In general, these results are in agreement with those previously reported after 7 days of BrdU incubation (Villar-Cheda et al., 2006).

When increasing the exposition time to BrdU to 16 days (Figures 3C,F), the number of BrdU-labeled cells increase in most portions of the lamprey telencephalon. In some regions such as the septum or the olfactory bulb practically all the periventricular cells are labeled, whereas in other regions the labeled cells are more or less homogeneously dispersed. In animals exposed 25 days to BrdU virtually all the periventricular cells are labeled, with 


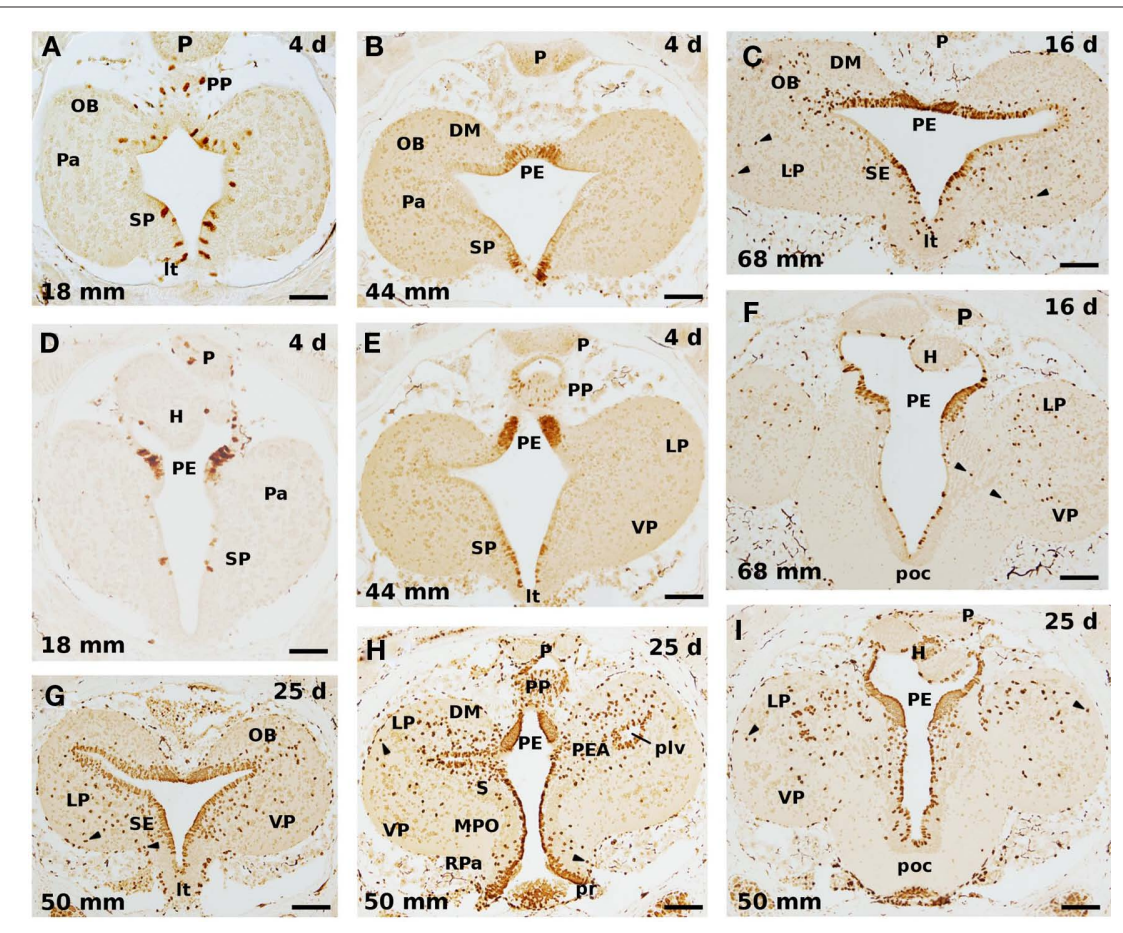

FIGURE 3 | Cell proliferation in transverse sections of the developing sea lamprey forebrain after incubation of 4 (A,B,D,E), 16 (C,F), and 25 (G-I) days in BrdU. (A-C), and (G), as well as (D-F), and (I), illustrate comparable rostrocaudal levels in larvae of different size, whereas $(\mathbf{H})$ is intermediate between (G) and (I). There is a general increase of immunolabeled cells with the increase of the BrdU exposure time. Note also that numerous migrating labeled cells are detected after 16 days of incubation with this marker (C,F), and that its number increases with longer incubations (25 days; G-I); most of them are located at dorsal (pallial) levels. In addition, a prominent BrdU labeling is present in the periventricular portion of the still small prethalamic eminence in all cases. Arrowheads point to laterally displaced labeled cells. $\mathrm{OB}$, olfactory bulb; $\mathrm{DM}$, dorsomedial neuropile; $\mathrm{H}$, habenula; $L P$, lateral pallium; It, lamina terminalis; MPO, medial preoptic nucleus; P, pineal organ; $\mathrm{Pa}$, pallium; $\mathrm{PE}$, prethalamic eminence; PEA, pallial extended amygdala; plv, posterior lateral ventricle; poc, postoptic commissure; PP, parapineal; pr, preoptic recess; $\mathrm{RPa}$, rostral paraventricular area; $\mathrm{S}$, striatum; $\mathrm{SE}$, septum; $\mathrm{SP}$, subpallium; VP, ventral pallium. Scale bars: $(\mathbf{A}, \mathbf{D}, \mathbf{G})=60 \mu \mathrm{m}$; $(B, C, E, F, H, I)=80 \mu \mathrm{m}$. thicker proliferation strata in those regions where more staining was already present with shorter exposition times (Figures 3G-I). Curiously enough, the prethalamic eminence area is completely full of BrdU-labeled cells, which means that almost all, if not all, cells in this structure appear to still be proliferating cells in larvae of middle size (50 mm larvae; Figures 3H,I). Although anatomically expected due to the large increase of this structure during the larval period, the physiological purpose of this very high and prolonged mitotic activity in this structure is not understood. These results are in agreement with those reported by Pfister (1971b,c), who claimed that the telencephalic primordium hippocampi (our prethalamic eminence), as well as the optic tectum, continues to proliferate for a particularly long time.

These results, as pointed out by Villar-Cheda et al. (2006), show that there is an important proliferation activity in the ventricular zone that last for several years. The presence of a conspicuous postembryonic neurogenesis in lampreys is, most likely, related to the slow and gradual development of these animals with some systems, such as the olfactory, visual, or oculomotor systems (Kleerekoper, 1982; de Miguel et al., 1990; Rubinson, 1990; Pombal et al., 1994; Rodicio et al., 1995; Zielinski et al., 2005), developing throughout the larval and metamorphic periods. A heavy PCNA expression was also observed around the ventricular zone of early prolarvae (Guérin et al., 2009).
Another conspicuous morphological feature of lampreys is that they possess a laminar brain, which means that there is little cellular migration, with most cells located in a more or less continuous and relatively thick periventricular stratum (Nieuwenhuys and Nicholson, 1998; Osório and Rétaux, 2008; Pombal and Megías, in press). However, a number of neurons and neuronal populations migrate away from the central gray zone and are embedded in the white matter. Actually, the telencephalon is one of the brain parts where more cells migrate away from the ventricular proliferative epithelium. The migration process starts early on during development and is particularly evident at pallial levels (see Figures 2C,D,F). After incubation with BrdU during 4 days, however, no labeled cell was observed outside the periventricular proliferating epithelium. In a previous study (Villar-Cheda et al., 2006), practically all the BrdU-labeled nuclei were located within or very close to the ventricular zone after a week of exposure to BrdU. These results indicate that the time for the differentiating neuroblast to migrate outside of the ventricular zone is higher than 7 days. In larvae exposed to the BrdU during 16 days (Figures 3C,F), a considerable number of BrdU-labeled cells appear laterally displaced in the neural tube, with some of them located far away from the ventricular surface (arrowheads in Figures 3C,F). This fact implies that 16 days is enough time for those cells that enter their differentiation to get out of the central matrix and populate the lateral 
(marginal) zone. When the animals are exposed 25 days to BrdU, the number of migratory postmitotic labeled cells is much higher, with some spreading in the whole extension of the periventricular cell strata, whereas others can be observed nearly to the outer surface of the brain (arrowheads in Figures 3G-I). These migrating cells are particularly abundant in the evaginated portion of the telencephalon, being more numerous in the lateral pallium. In this portion of the brain, the wall is slightly thicker and contains a higher number of laterally displaced (migrated) cells in adult specimens. In a previous study in the lamprey rhombencephalon and spinal cord with BrdU labeling, however, in addition to the non-neuronal identification of the labeled cells, it was concluded that there is no migration of BrdU-labeled cells even when the animals were killed 52 days after the injection of the cell proliferation marker (VidalPizarro et al., 2004). Although our largest incubation time in BrdU was 25 days, there is a clear pattern of cellular migration showing a correlation between exposition time and traveled distance from the ependymal zone, as well as a gradual increase in the number of lateral displaced labeled cells (see Figure 3). This disparity may, in part, be explained by dilutional effects of multiple mitoses on labeling due to the different protocol employed (see above).

It is noteworthy that the majority of the neurons in the brain of myxines migrate away from the proliferative periventricular area, and, in the pallium, in particular, most cells are clearly segregated in several layers, thus being laminated in appearance (reviewed in Ronan and Northcutt, 1998; Wicht and Nieuwenhuys, 1998; Pombal and Megías, in press); up to now, however, there is no clear correspondence between the different pallial subdivisions recognized in either myxines or lampreys with those established in amniote vertebrates. In addition, it is not known whether the situation in lampreys is an ancestral or a derived character.

\section{GABAergic SYSTEM}

In adult lampreys there are many GABA-ir cells throughout the brain and the spinal cord, part of which are of cerebrospinal fluid-contacting type cells (CSF-c; see Robertson et al., 2007, for a review). Concerning the adult lamprey telencephalon, the presence of GABA-ir cells has been previously reported by different authors (Pombal et al., 1997; Meléndez-Ferro et al., 2001; Robertson et al., 2007), which are located in the olfactory bulbs, the pallium, and the subpallium (Figures 4A-C). In a detailed study of the olfactory bulbs, Meléndez-Ferro et al. (2001) identified several GABAergic cell populations, including periglomerular cells located around the olfactory glomeruli, cells in the inner cellular layer, some CSF-c at the ventricular level, as well as some cells at the entrance of the olfactory nerve and in the interbulbar commissure. At pallial level, GABA-ir cells were observed inside the limits of the lateral, dorsal, and medial pallia (Figures 4A-C; Pombal and Puelles, 1999; Robertson et al., 2007), with the last two corresponding to our pallial extended amygdala and prethalamic eminence, respectively (see Pombal et al., 2009; Martínez-de-la-Torre et al., 2011; Pombal and Megías, in press). In the subpallium, GABA-ir cells distribute in the nucleus of the anterior commissure, the septum, and the striatum (Figure 4A; Pombal et al., 1997; Robertson et al., 2007). In these subpallial nuclei there are many CSF-c cells bearing an apical dendrite that ends at the ventricular surface. Additionally, it was recently shown that a number of GABAergic cells located in the caudal part of the medial pallium (our prethalamic eminence) project to the lamprey optic tectum (Robertson et al., 2006). Furthermore, some GABA-ir neurons within the same area as well as a few located in the ventral part of the lateral pallium (our ventral pallium) project to the mesencephalic locomotor region (MLR) of the isthmic region (Ménard et al., 2007). Based on the presence of GABA-ir projection neurons, these authors suggested that the two pallial areas of the lamprey could be considered analogous to the amygdala and/or pallidum of tetrapods (Ménard et al., 2007). An interesting aspect, however, is how this adult GABAergic system is acquired during development? By using immunohistochemical methods, we have studied in detail the early development of the lamprey GABAergic system in both transverse and sagittal semithin sections of the lamprey prosencephalon to get insight on the differentiation and evolution of its GABAergic system.

The first telencephalic immunolabeled cells appear after hatching (by $18 \mathrm{dpf}$ prolarvae), in the outer part of the periventricular proliferating layer of the primordial hemispheres (Figure 4D). They are few in number, locate slightly rostral to the small primordium of the optic chiasma, and have short processes running laterally. These GABA-ir cells must correspond to the primordium of the subpallium and, at least part of them are of CSF-c type; it should be noted, however, that at this stage there is no recognizable morphological landmark indicating the boundary between the pallial and non-pallial telencephalic portions. Two days later (20 dpf; Figures 4E,H), the number of GABA-ir cells increase considerably in the subpallium with some of them laterally migrated, at the time that the first immunoreactive cells and processes appear more rostrally (and dorsally) in the primordial telencephalic hemispheres. In sagittal sections, a few GABA-ir cells are seen inside the presumptive pallial primordium (Figure $4 \mathbf{H}$ ).

In $23 \mathrm{dpf}$ prolarvae (Figures 4F,I), the number of GABA-ir cells continues increasing as do the labeled processes in the ventrolateral margin of the neural tube at the subpallium. Many of these cells distribute in the dorsorostral portion of the telencephalic hemispheres, at the time that the cephalic flexure is partially reduced because of the dorsal shift of the rostral neural tube (see above and Figure 1). At this stage, two GABAergic cell populations can be distinguished: a prominent ventral (subpallial) population and a less conspicuous dorsal (pallial) population; both of them are formed by a relatively compact mass of GABA-ir cells in the lateral portion of the matrix zone, with some cells displaced laterodorsally (Figure 4F). At the external surface, a slight depression indicates the approximate boundary between the pallial and subpallial portions. The dorsalization of the labeled cells is better observed in sagittal sections (compare Figures $\mathbf{4 H}, \mathbf{I}$ ), where those locate in the dorsal (pallial) portion of the telencephalic hemispheres appear as slightly larger and more intense labeled. In addition, at the rostral end of the neural tube numerous CSF-c GABA-ir cells of the subpallial population locate medially close to the lamina terminalis (Figure 4F).

By $29 \mathrm{dpf}$ prolarvae (Figure 4G), the shape of the evaginated portion of the telencephalon is better discernible from the impar non-evaginated portion. In this stage, the primordium of the septum and the striatum is now better differentiated from the GABA-ir population located close by to the optic chiasma mostly composed of CSF-c neurons (Figure 4G). Both populations of labeled cells are separated by a GABA negative portion that is 


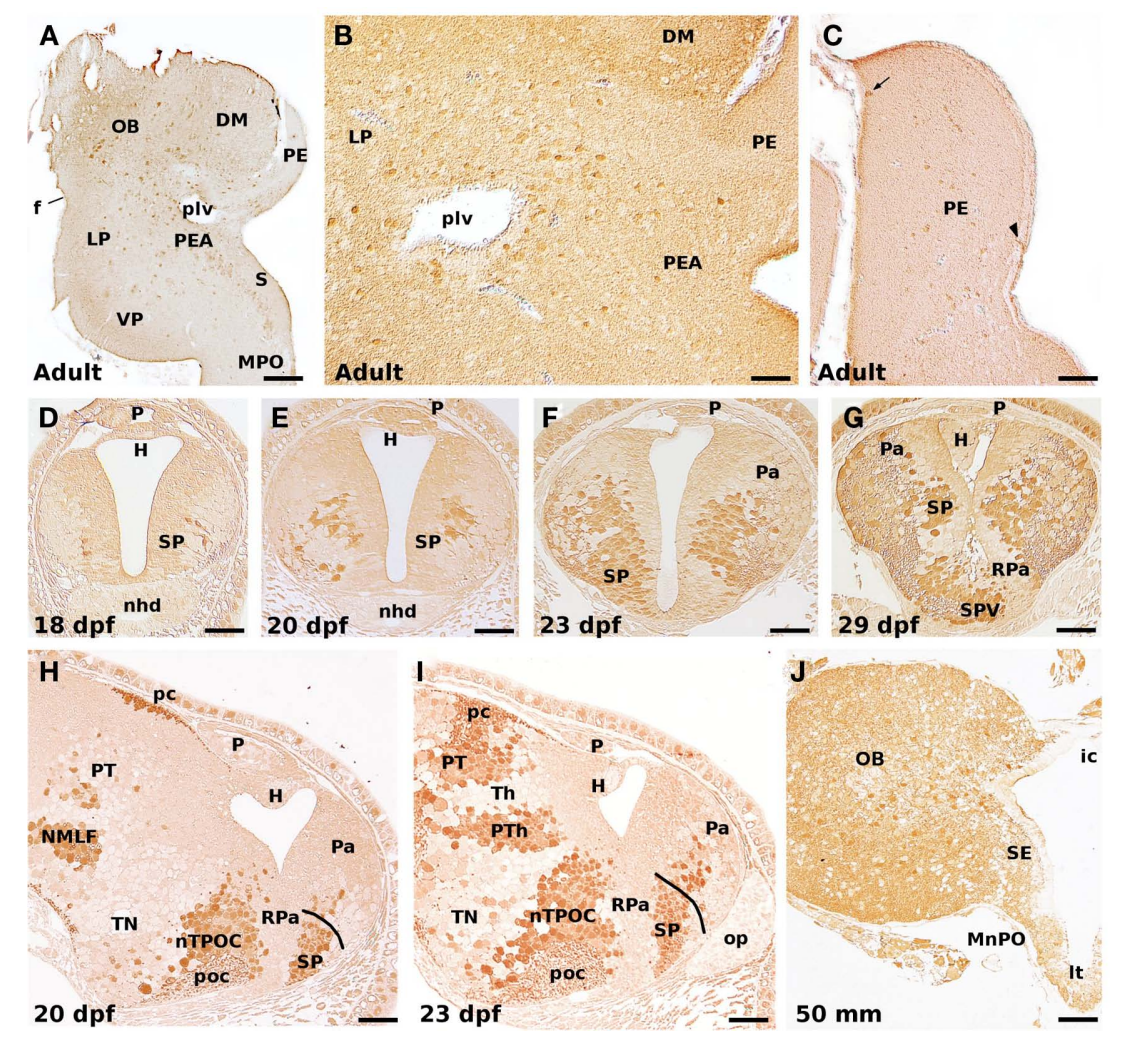

FIGURE 4 | GABA-ir cells in the adult (A-C), developing prolarvae (D-I), and midlarval lamprey telencephalon (J). (A) Transverse section illustrating GABA-ir cells in the olfactory bulb, lateral and ventral pallium, pallial extended amygdala, striatum, and medial preoptic nucleus. (B) GABA-ir cells in the lateral pallium, and the pallial extended amygdala. (C) GABA-ir cells in the prethalamic eminence. Most of its GABA-ir cells are dispersed at intermediate levels, but a few can be observed at either the medial (ventricular; arrowhead) or lateral (superficial; arrow) borders. Transverse (D-G), and sagittal $(\mathbf{H}, \mathbf{I})$ sections of prolarvae of different size illustrating the early development of the telencephalic GABAergic cells. Note the increase in the number of GABA-ir cells as well as the progressive colonization of dorsal (pallial) areas. (J) GABA-ir cells in the olfactory bulb, septum, and median preoptic nucleus of a 50-mm larva. In sagittal sections
$(\mathbf{H}, \mathbf{I})$, rostral is to the right. OB, olfactory bulb; DM, dorsomedial neuropile; $f$, fissura circularis; $H$, habenula; ic, interbulbar commissure; LP, lateral pallium; It, lamina terminalis; MnPO, median preoptic nucleus; MPO, medial preoptic nucleus; nhd, nasohypophyseal duct; NMLF, nucleus of the medial longitudinal fascicle; nTPOC, nucleus of the tract of the postoptic commissure; op, olfactory placode; $\mathrm{P}$, pineal organ; $\mathrm{Pa}$, pallium; $\mathrm{pc}$, posterior commissure; $\mathrm{PE}$, prethalamic eminence; PEA, pallial extended amygdala; plv, posterior lateral ventricle; poc, postoptic commissure; PT, pretectum; PTh, prethalamus; RPa, rostral paraventricular area; S, striatum; SE, septum; SP, subpallium; SPV, subparaventricular area; Th, thalamus; TN, tuberal nucleus; VP, ventral pallium. Scale bars: $(\mathbf{A})=100 \mu \mathrm{m} ;(\mathbf{B})=50 \mu \mathrm{m} ;(\mathbf{C})=60 \mu \mathrm{m} ;(\mathbf{D}-\mathbf{G}, \mathbf{I})=30 \mu \mathrm{m}$; (H) $=40 \mu \mathrm{m} ;(\mathbf{J})=70 \mu \mathrm{m}$. now conceived as the anlage of the rostral paraventricular nucleus (Pombal et al., 2009; reviewed in Pombal and Megías, in press), and corresponds to the classical preoptic magnocellular nucleus. Therefore, according to present-day definition of the preoptic area in tetrapods, both portions, the anlage of the rostral paraventricular nucleus and the immediately ventral GABA-ir band do not belong to the telencephalon. Of note, this pattern of GABA-ir cells is in neatly agreement with both the Dlx expression in embryonic and early prolarval stages (Murakami et al., 2001; Myojin et al., 2001; Neidert et al., 2001; Kuraku et al., 2010), and DLL (a homeobox transcription factor)-ir in midlarval stages (Martínezde-la-Torre et al., 2011).

In medium-sized larvae, the pattern of GABA-ir cells is similar to that reported for adult specimens (Figure 4J; Meléndez-Ferro et al., 2002a; Robertson et al., 2007); at this stage, however, there are no GABA-ir cells in the prethalamic eminence (the classical medial pallium; see below). This is because this structure is basically undifferentiated with practically all of its cells actively proliferating, as commented above (see also Figure 3). In addition, it is worth noting that the pattern of DLL positive cells in larvae of similar size is consistent with a possible tangential migration from the proliferating periventricular subpallium to the pallium (Martínezde-la-Torre et al., 2011), as reported for several gnathostome species (Dirksen et al., 1993; Cobos et al., 2001; Brox et al., 2003; Carrera et al., 2008; Moreno et al., 2008; reviewed in Puelles et al., 2000; Marín and Rubenstein, 2001, 2003).

These results mostly agree with those previously published on the ontogeny of the GABA-ir populations in the forebrain and midbrain of the sea lamprey (Meléndez-Ferro et al., 2002a), with some minor differences that may be due to the temperature used to raise embryos and prolarvae $\left(18^{\circ} \mathrm{C}\right.$ versus $\left.16^{\circ} \mathrm{C}\right)$.

In the last years, the expression patterns of several regulatory genes were studied during the embryonic and early prolarval development showing striking similarities with those reported in gnathostomes, but also some differences. Therefore, although the developmental program for the brain appears to be quite 
conservative, there are also some differences concerning the mechanisms of brain patterning and organization. One of these differences concerns the specification of the GABAergic cells in the lamprey telencephalon (reviewed in Osório and Rétaux, 2008; Watanabe et al., 2008). Analysis of the expression pattern of $H h$ (a Shh homolog) and Nkx2.1 (TTF-1) in early developing lampreys revealed the presence of two basal plate domains located in the hypothalamus and the ventral aspect of the neural tube including the zona limitans intrathalamica, but the lack of expression in the subpallium (Murakami et al., 2001, 2005; Ogasawara et al., 2001; Uchida et al., 2003; Kluge et al., 2005; Osório et al., 2005; Kano et al., 2010; reviewed in Kuratani et al., 2002; Murakami et al., 2005; Osório and Rétaux, 2008; Watanabe et al., 2008; Murakami and Watanabe, 2009). This fact raised the question on the existence in lampreys of a homolog of the medial ganglionic eminence (MGE) of gnathostome vertebrates, which, in these animals, represents the major source of cortical (pallial) interneurons by originating a conspicuous tangential migratory stream of GABAergic cells that enter several pallial portions (Moreno et al., 2008; reviewed in Marín and Rubenstein, 2001, 2003). The first GABA-ir cells in the lamprey subpallium are observed by Piavis stage 17 (18 dpf; Meléndez-Ferro et al., $2002 \mathrm{a}$; present results), which is slightly latter than the stages analyzed for $H h$ and $N k x 2.1$. In this scenario, there are, at least, three different interpretations or possibilities for the origin of the GABA-ir telencephalic cells in lampreys: (1) they do have a true homolog of the MGE of gnathostomes but the expression of $H h$ and $N k \times 2.1$ is somehow delayed during development, as it is for the histological differentiation. A significant delay, as compared with gnathostomes, on the telencephalic expression has also been observed for $F g f 8 / 17$ (Guérin et al., 2009); (2) the pallial GABA-ir cells of these animals are originated exclusively from a hypothetical homolog of the gnathostome lateral ganglionic eminence (LGE; see also Watanabe et al., 2008), which has also been reported to contribute to the GABAergic pallial interneurons (see Rubin et al., 2010 and references herein); (3) alternatively, the lamprey GABA-ir pallial neurons could be originated through a different specification mechanism from those known in gnathostomes, as already suggested by Osório and Rétaux (2008). Needless to say that a combination of these options is also possible.

\section{STRUCTURE AND REGIONALIZATION OF THE LAMPREY TELENCEPHALON}

The lamprey telencephalon, which is now considered to be the most rostrodorsal portion of the alar plate of the secondary prosencephalon (Pombal et al., 2009; Pombal and Megías, in press), comprises three main parts: the olfactory bulbs, the cerebral hemispheres, and the telencephalon medium (the unevaginated portion; Nieuwenhuys and Nicholson, 1998). The dorsocaudal limit of the telencephalon varied considerably across the literature (Figure 5), and some recent changes have also been introduced on its ventral limit, as already commented.

The internal organization of the olfactory bulbs is quite similar to that of other anamniote vertebrates (Heier, 1948; Schnitzlein, 1982; Iwahori et al., 1987; reviewed in Ren et al., 2009). It is noteworthy that the olfactory bulbs of these animals are larger than the

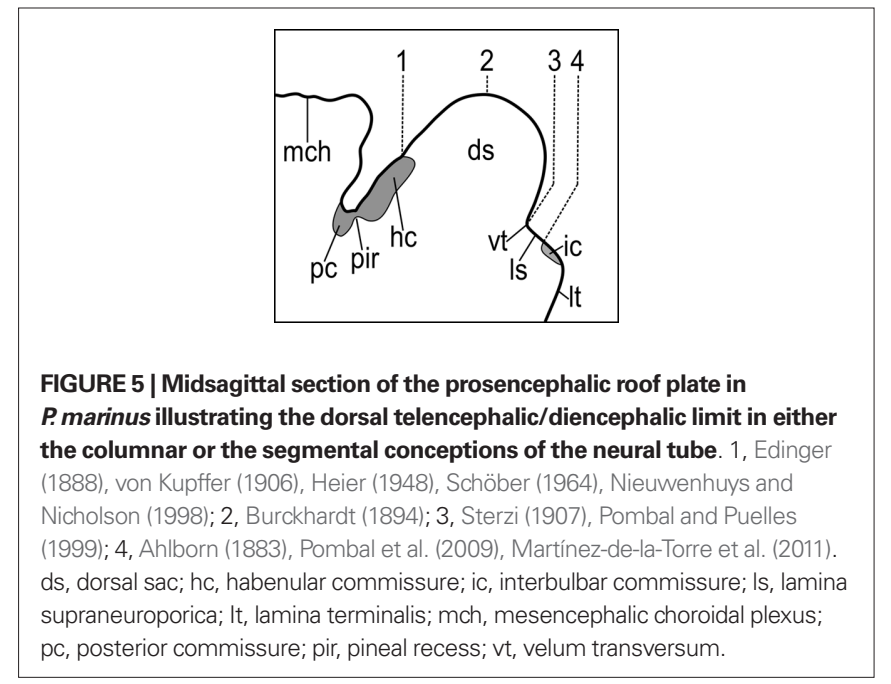

cerebral hemispheres from which they are externally demarcated by a shallow groove, the circular fissura. Both of them are hollow structures with their ventricles connected with the median third (diencephalic) ventricle through a common interventricular foramen (or foramen of Monroe).

The cerebral hemispheres and the telencephalon medium can be subdivided into a dorsal pallial region and a ventral subpallial region, with the later including the septum, striatum, and preoptic region. The organization of the lamprey pallium is still a matter of discussion, and different conceptions have been postulated in the last decades (Figure 6). Most of the classical studies considered four main subdivisions: primordium hippocampi (or medial pallium) of Johnston (1912), primordium pallii dorsalis (or dorsal pallium), primordium piriforme (or lateral pallium), and lobus (lobulus) subhippocampalis (or subhippocampal lobe) of Herrick and Obenchain (1913) (Heier, 1948; Schöber, 1964; reviewed in Nieuwenhuys and Nicholson, 1998; Pombal et al., 2009). A major difference concerns the interpretation of the subhippocampal lobe as the homolog of the dorsal pallium of tetrapods, as well as the consideration of the evaginated portion as a lateral pallium homolog, which was further subdivided into dorsal and ventral parts (Northcutt and Puzdrowski, 1988). With the postulation of the lamprey prosomeric model (Pombal and Puelles, 1999), the homology of the dorsal pallium was initially rejected and its previous name (subhippocampal lobe) adopted again. Finally, the most recent conception has recognized a putative ventral pallium homolog in the ventral part of the evaginated portion, whereas the subhippocampal lobe was interpreted as a portion of the amygdala, the pallial extended amygdala (Pombal et al., 2009; Martínezde-la-Torre et al., 2011; Pombal and Megías, in press). A primordial amygdala was first recognized by Schnitzlein (1982), who described this structure as a mass of scattered cells at the ventromedial border of the primordial piriform. In addition, the classical primordium hippocampi of Johnston (1912) or medial pallium was considered as homolog of the prethalamic eminence (as already considered by several earlier authors; reviewed in Pombal et al., 2009). This interpretation is consistent with its topological position in relation with both, the interventricular 


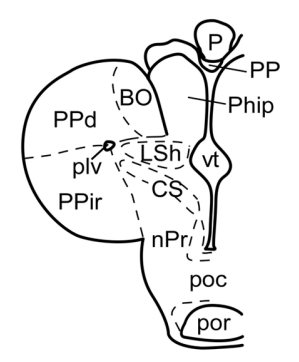

Heier (1948), Schöber (1964) Nieuwenhuys and Nicholson (1998)

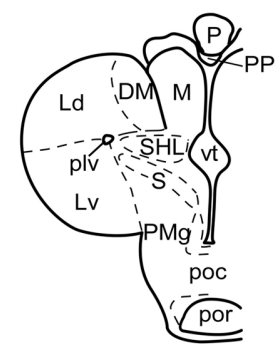

Pombal and Puelles (1999)

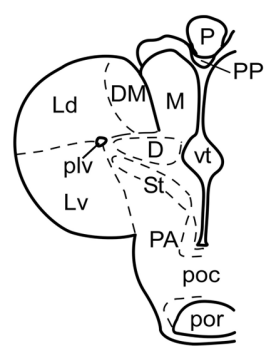

Northcutt and Puzdrowski (1988)

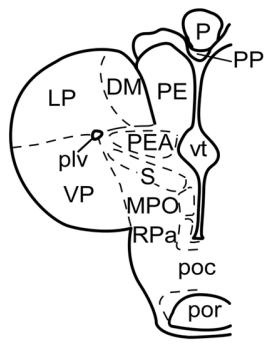

Pombal et al., (2009), Pombal and Megías, in press

FIGURE 6 | Schematic drawings of a transverse section through the adult lamprey telencephalon and rostral hypothalamus showing the evolution of the nomenclature of the different nuclei and areas. $\mathrm{BO}$, bulbus olfactorius; CS, corpus striatum; D, dorsal pallium; DM, dorsomedial telencephalic neuropile; Ld, lateral pallium, dorsal part; LP, lateral pallium; LSh; lobulus subhippocampalis; M, medial pallium; Lv, lateral pallium, ventral part; MPO, medial preoptic nucleus; $\mathrm{nPr}$, nucleus preopticus; P, pineal organ; PA, preoptic area; $\mathrm{PE}$, prethalamic eminence; $\mathrm{PEA}$, pallial extended amygdala; Phip, primordium hippocampi; plv, posterior lateral ventricle; PMg, magnocellular preoptic nucleus; poc, postoptic commissure; por, postoptic recess; PP, parapineal; PPd, primordium pallium dorsalis; PPir, primordium piriforme; $\mathrm{RPa}$, rostral paraventricular area; $\mathrm{S}$, striatum; $\mathrm{SHL}$, subhippocampal lobe; St, striatum; VP, ventral pallium; vt, impar telencephalic ventricle.

foramen and the velum transversum, as well as with the presence of Lhx1/5 mRNA (Osório et al., 2006), a marker of the prethalamic eminence in tetrapods (Moreno et al., 2004). Moreover, the presence of a number of GABA-ir cells in this structure in adult lampreys (see Figure 4C) could be equally explained for both conceptions (it should be keep in mind that in gnathostome vertebrates GABAergic cells were reported in both of them): they could be originated as part of those migrating from the subpallium (medial pallium conception), or from the alar portion of the prethalamus, which also has Dlx expressing cells (Murakami et al., 2001; Myojin et al., 2001; Neidert et al., 2001; Kuraku et al., 2010) and DLL-ir cells (Martínez-de-la-Torre et al., 2011; prethalamic eminence conception).

Some progress regarding the regionalization of the adult lamprey forebrain has been recently achieved based on the specific presence of neurotransmitters or related neurochemicals, of neuroanatomical connections as well as of the expression pattern of a number of developmental regulatory genes. Some of them, such as Pax6, Dlx1/6, and $L h \times 1 / 5$, are useful markers of different interprosomeric boundaries or their internal subdivisions. Concerning the telencephalon, Pax6 is expressed in its dorsal

(pallial) portion (Murakami et al., 2001; Derobert et al., 2002; Uchida et al., 2003; Osório et al., 2005; reviewed in Kuratani et al., 2002; Murakami et al., 2005; Murakami and Watanabe, 2009), whereas $D l \times 1 / 6$ is expressed ventrally (subpallium; Murakami et al., 2001; Myojin et al., 2001; Neidert et al., 2001; Kuraku et al., 2010; reviewed in Kuratani et al., 2002; Murakami et al., 2005; Murakami and Watanabe, 2009), therefore the boundary of their expressing areas do correspond to the pallial/subpallial boundary. This limit is also recognized with an antibody against the Drosophila distal-less protein (Martínez-de-la-Torre et al., 2011). In addition, Emx (a marker of the dorsal, medial, and lateral pallia in gnathostomes) is expressed in the dorsalmost portion of the primordial pallium in late embryos and early prolarvae (Myojin et al., 2001; reviewed in Kuratani et al., 2002; Murakami et al., 2005; Murakami and Watanabe, 2009). Though that more data are necessary, these results suggest that some of the major subdivisions of the gnathostome telencephalon are also present in lampreys.

\section{CONCLUDING REMARKS}

The lamprey forebrain undergoes some important topographical rearrangements during early postembryonic development, and, after that, it grows slowly through an extremely large larval period, with new born cells being added at different rates in virtually all the telencephalic subdivisions. Our detailed study on the distribution and morphological developmental pattern of the GABA-ir cells in the telencephalon of prolarvae reinforce the previously postulated subpallial/pallial migratory pathway in lampreys (Meléndez-Ferro et al., 2002a; Martínez-de-la-Torre et al., 2011), and also suggested for sharks (Carrera et al., 2008); therefore, the characteristic tangential neuronal migration from the subpallium to the pallium described in tetrapods is likely to be already present in agnathans and elasmobranch fishes.

Concerning the general telencephalic organization in lampreys, there is now a general agreement on the subpallial areas, with the recently included preoptic area, but less at pallial level, with new ideas and propositions coming out with the increasing amount of experimental data. In the recently proposed prosomeric model for lampreys, the alar plate of the secondary prosencephalon includes the new conception of the telencephalon, which encompasses the preoptic area, and the alar hypothalamus; in addition, the alar plate of p3 becomes quite enlarged due to the consideration of the classical medial pallium as part of the prethalamic eminence. The available results indicate that the lamprey telencephalon possess a more complex organization than previously though. The increasing data on gene expression, and their combination with chemoarchitectural and hodological techniques, will be useful tools for unraveling the characterization of the telencephalic regions and nuclei in lampreys, providing better comparisons with their counterparts in other vertebrates, in order to clarify the basic molecular mechanisms necessary to originate brain compartments as well as their evolution.

\section{ACKNOWLEDGMENTS}

This work was supported by Spanish MEC-FEDER (grant number BFU2006-14127), Spanish MICINN-FEDER (grant number BFU2009-13369), and University of Vigo (grant number 07V1A12). 


\section{REFERENCES}

Ahlborn, F. (1883). Untersuchungen über das Gehirn der Petromyzonten. Z. Wissensch. Zool. XXXIX, 191-294.

Álvarez-Otero, R., Megías, M., and Pombal,M.A. (2002). “Postembryonic cell proliferation in the sea lamprey central nervous system," in FENS Forum, Paris (Abstr. A 137.1, 171).

Bergquist, H. (1952). Studies on the cerebral tube in vertebrates. The neuromeres. Acta Zool. 33, 117-187.

Bergquist, H., and Källén, B. (1953). Studies on the topography of the migration areas in the vertebrate brain. Acta Anat. (Basel) 17, 353-369.

Brox, A., Puelles, L., Ferreiro, B., and Medina, L. (2003). Expression of the genes GAD67 and Distal-less-4 in the forebrain of Xenopus laevis confirms a common pattern in tetrapods. $J$. Comp. Neurol. 461, 370-393.

Burckhardt, R. (1894). Zur Homologieen des Zwischenhirndaches und ihre Bedeutung für die Morphologie des Hirns bei niedern Vertebraten. Anat. Anz. IX, 152-155.

Carrera, I., Ferreiro-Galve, S., Sueiro, C., Anadón, R., and Rodríguez-Moldes, I. (2008). Tangentially migrating GABAergic cells of subpallial origin invade massively the pallium in developing sharks. Brain Res. Bull. 75, 405-409.

Cobos, I., Puelles, L., and Martínez, S. (2001). The avian telencephalic subpallium originates inhibitory neurons that invade tangentially the pallium (dorsal ventricular ridge and cortical areas). Dev. Biol. 239, 30-45.

Damas, H. (1944). Recherches sur le développement de Lampetra fluviatilis L. Contribution à l'étude de la céphalogenèse des vertébrés. Arch. Biol. 25, 1-284.

de Miguel,E., Rodicio, M.C., and Anadón, R. (1990). Organization of the visual system in larval lampreys: an HRP study. J. Comp. Neurol. 302, 529-542.

Derobert, Y., Baratte, B., Lepage, M., and Mazan, S. (2002). Pax6 expression patterns in Lampetra fluviatilis and Scyliorhinus canicula embryos suggest highly conserved roles in the early regionalization of the vertebrate brain. Brain Res. Bull. 57, 277-280.

Dirksen, M. L., Mathers, P., and Jamrich, M. (1993). Expression of a Xenopus distal-less homeobox gene involved in forebrain and cranio-facial development. Mech. Dev. 41, 121-128.

Edinger, L. (1888). Untersuchungen über die vergleichende Anatomie des Gehirns. I. Das Vorderhirn. Abhandlungen der Senckenbergischen Naturforschenden Gesellschaft. Bd.XV, 91-122.

Guérin, A., d'Aubenton-Carafa, Y., Marrakchi, E., Da Silva, C., Wincker, P., Mazan, S., and Rétaux, S. (2009).
Neurodevelopment genes in lampreys reveal trends for forebrain evolution in craniates. PLoS ONE 4, e5374. doi: 10.1371/journal.pone.0005374

Hardisty, M. W., and Potter, I. C. (1971). "The behaviour, ecology and growth of larval lampreys," in The Biology of Lampreys, Vol. 1, eds M. W. Hardisty and I. C. Potter (London: Academic Press), 85-125.

Healey, E. G. (1972). "The central nervous system," in The Biology of Lampreys, Vol. 2, eds M. W. Hardisty and I. C. Potter (London: Academic Press), 307-372.

Heier, P. (1948). Fundamental principles in the structure of the brain. Acta Anat. VII, 1-213.

Herrick, C. J., and Obenchain, J. B. (1913). Notes on the anatomy of a cyclostome brain: ichthyomyzon concolor. $J$. Comp. Neurol. 23, 635-675.

Iwahori, N., Kiyota, E., and Nakamura, K. (1987). A Golgi study on the olfactory bulb in the lamprey, Lampetra japonica. Neurosci. Res. 5, 126-139.

Johnston, J. B. (1912). The telencephalon in cyclostomes. J. Comp. Neurol. 22, 341-404.

Källén, B. (1951). Contributions to the ontogeny of the nuclei and the ventricular sulci in the vertebrate forebrain. Kungl. Fysiogr. Sällsk. Lund Handl. N. F. 62, 5-34.

Kano, S., Xiao, J., Osório, J., Ekker, M., Hadzhiev, Y., Müller, F., Casane, D., Magdelenat, G., and Rétaux, S. (2010). Two lamprey hedgehog genes share non-coding regulatory sequences and expression patterns with gnathostome hedgehogs. PLoS ONE 5, e13332. doi: 10.1371/journal.pone.0013332

Kleerekoper, H. (1982). "The sense organs," in The Biology of Lampreys, Vol. 2, eds M. W. Hardisty and I. C. Potter (London: Academic Press), 373-404.

Kluge, B., Renault, N., and Rohr, K. B. (2005). Anatomical and molecular reinvestigation of lamprey endostyle development provides new insight into thyroid gland evolution. Dev. Genes Evol. 215, 32-40.

Kuraku, S., Takio, Y., Sugahara, F., Takechi, M., and Kuratani, S. (2010). Evolution of oropharyngeal patterning mechanisms involving Dlx and endothelins in vertebrates. Dev. Biol. 341,315-323.

Kuratani, S., Kuraku, S., and Murakami, Y. (2002). Lamprey as an evo-devo model: lessons from comparative embryology and molecular phylogenetics. Genesis 34, 175-183.

Kuratani, S., Nobusada, Y., Horigome, N., and Shigetani, Y. (2001). Embryology of the lamprey and evolution of the vertebrate jaw: insights from molecular and developmental perspectives. Philos. Trans. R. Soc. Lond., B, Biol. Sci. 356, 1615-1632.
Marín, O., and Rubenstein, J. L. R. (2001). A long, remarkable journey: tangential migration in the telencephalon. Nat. Rev. Neurosci. 2, 780-790.

Marín, O., and Rubenstein, J. L. R. (2003). Cell migration in the forebrain. Annu. Rev. Neurosci. 26, 441-483.

Martínez-de-la-Torre, M., Pombal, M. A., and Puelles, L. (2011). Distal-lesslike protein distribution in the larval lamprey forebrain. Neuroscience 178 270-284.

Meeuwig, M. H., Bayer, J. M., and Reiche, R. A. (2006). Morphometric discrimination of early life stage Lampetra tridentata and L. richardson (Petromyzonidae) from the Columbia River Basin. J. Morphol. 267, 623-633.

Meléndez-Ferro, M., Pérez-Costas, E., Rodríguez-Muñoz, R., Gómez-López, M. P., Anadón, R., and Rodicio, M. C. (2001). GABA immunoreactivity in the olfactory bulbs of the adult sea lamprey Petromyzon marinus L. Brain Res. 893, 253-260.

Meléndez-Ferro, M., Pérez-Costas, E., Villar-Cheda, B., Abalo, X. M., Rodríguez-Muñoz, R., Rodicio, M.C., and Anadón, R. (2002a). Ontogeny of gamma-aminobutyric acid-immunoreactive neuronal populations in the forebrain and midbrain of the sea lamprey. J. Comp. Neurol. 446, 360-376.

Meléndez-Ferro,M.,Villar-Cheda, B.,Abalo, X. M., Pérez-Costas, E., RodríguezMuñoz, R., Degrip, W. J., Yáñez, J. Rodicio, M.C., and Anadón, R. (2002b) Early development of the retina and pineal complex in the sea lamprey: comparative immunocytochemical study. $J$ Comp. Neurol. 442, 250-265.

Ménard, A., Auclair, F., Bourcier-Lucas, C., Grillner, S., and Dubuc, R. (2007). Descending GABAergic projections to the mesencephalic locomotor region in the lamprey Petromyzon marinus. J. Comp. Neurol. 501, 260-273.

Moreno, N., Bachy, I., Rétaux, S., and González, A. (2004). LIMhomeodomain genes as developmental and adult genetic markers of Xenopus forebrain functional subdivisions. J. Comp. Neurol. 472, 52-72.

Moreno, N., González, A., and Rétaux, S. (2008). Evidences for tangential migrations in Xenopus telencephalon: developmental patterns and cell tracking experiments. Dev. Neurobiol. 68 504-520.

Murakami, Y., Ogasawara, M., Sugahara, F., Hirano, S., Satoh, N., and Kuratani, S. (2001). Identification and expression of the lamprey Pax6 gene: evolutionary origin of the segmented brain of vertebrates. Development 128, 3521-3531.

Murakami, Y., Uchida, K., Rijli, F. M., and Kuratani, S. (2005). Evolution of the brain developmental plan: insights from agnathans. Dev. Biol. 280, 249-259.

Murakami, Y., and Watanabe, A. (2009) Development of the central and peripheral nervous systems in the lamprey. Dev. Growth Diff. 51, 197-205.

Myojin, M., Ueki, T., Sugahara, F., Murakami, Y., Shigetani, Y., Aizawa, S., Hirano, S., and Kuratani, S. (2001). Isolation of Dlx and Emx gene cognates in an agnathan species, Lampetra japonica, and their expression patterns during embryonic and larval development: conserved and diversified regulatory patterns of homeobox genes in vertebrate head evolution. J. Exp. Zool. 291, 68-84.

Neidert, A. H., Virupannavar, V., Hooker, G. W., and Langeland, J. A. (2001). Lamprey Dlx genes and early vertebrate evolution. Proc. Natl. Acad. Sci. U.S.A. $98,1665-1670$

Nieuwenhuys, R., and Nicholson, C. (1998). “Lampreys, Petromyzontidae," in The Central Nervous System of Vertebrates, Vol. 1, eds R. Nieuwenhuys, H. J. ten Donkelaar, and C. Nicholson (Berlin: Springer-Verlag), 297-495.

Nikitina, N., Bronner-Fraser, M., and Sauka-Spengler, T. (2009). The sea lamprey Petromyzon marinus: a model for evolutionary and developmental biology. Cold Spring Harb. Protoc. 2009, pdb.emol13.

Northcutt, R. G., and Puzdrowski, R. L. (1988). Projections of the olfactory bulb and nervus terminalis in the silver lamprey. Brain Behav. Evol.32,96-107. Northcutt, R. G., and Wicht, H. (1997) Afferent and efferent connections of the lateral and medial pallia of the silver lamprey. Brain Behav. Evol. 49, 1-19.

Ogasawara, M., Shigetani, Y., Suzuki, S., Kuratani, S., and Satoh, N. (2001) Expression of thyroid transcription factor-1 (TTF-1) gene in the ventral forebrain and endostyle of the agnathan vertebrate, Lampetra japonica. Genesis 30, 51-58.

Osório, J., Mazan, S., and Rétaux, S. (2005). Organisation of the lamprey (Lampetrafluviatilis) embryonic brain: insights from LIM-homeodomain, Pax and hedgehog genes. Dev. Biol. 288, 100-112.

Osório, J., Megías, M., Pombal, M. A., and Rétaux, S. (2006). Dynamic expression of the LIM-homeodomain gene Lhx15 through larval brain development of the sea lamprey (Petromyzon marinus). Gene Expr. Patterns 6, 873-878.

Osório, J., and Rétaux, S. (2008). The lamprey in evolutionary studies. Dev. Genes. Evol. 218, 221-235.

Pfister, C. (1971a). Die Matrix im Gehirn von Neunaugenembryonen (Lampetra planeri) (Bloch 1874). Z Mikrosk. Anat. Forsch. 84, 485-492. 
Pfister, C. (1971b). Die Matrixentwicklung in Tel- und Diencephalon von Lampetra planeri (Bloch) (Cyclostomata) im Verlaufe de Individualklus. $J$. Hirnforsch. 13, 363-375.

Pfister, C. (1971c). Die Matrixentwicklung in Mes- und rhombencephalon von Lampetra planeri (Bloch) (Cyclostomata) im Verlaufe de Individualzyklus. J. Hirnforsch. 13, 377-383.

Piavis, G. W. (1961). Embryological stages in the sea lamprey and effects of temperature on development. U.S. Fish Wildl. Serv. Fish. Bull. 61, 111-143.

Piavis, G.W. (1971). "Embryology," in The Biology of Lampreys, Vol. 1, eds M. W. Hardisty and I. C. Potter (London: Academic Press), 361-400.

Polenova, O. A., and Vesselkin, N. P. (1993). Olfactory and nonolfactory projections in the river lamprey (Lampetra fluviatilis) telencephalon. J. Hirnforsch. 34, 261-279.

Pombal,M.A., de Arriba,M.C.,Sampedro, C., Alvarez, R., and Megías, M. (2002). Immunocytochemical localization of calretinin in the olfactory system of the adult lamprey, Lampetra fluviatilis. Brain Res. Bull. 57, 281-283.

Pombal, M.A., El Manira, A., and Grillner, S. (1997). Organization of the lamprey striatum - transmitters and projections. Brain Res. 766, 249-254.

Pombal, M. A., and Megías, M. (in press). "Functional morphology of the brain of agnathans," in Encyclopedia of Fish Physiology: From Genome to Environment, ed. T. Farrel (San Diego: Academic Press).

Pombal, M. A., Megías, M., Bardet, S. M., and Puelles, L. (2009). New and old thoughts on the segmental organization of the forebrain in lampreys. Brain Behav. Evol. 74, 7-19.

Pombal, M. A., and Puelles, L. (1999). Prosomeric map of the lamprey forebrain based on calretinin immunocytochemistry, Nissl stain, and ancillary markers. J. Comp. Neurol. 414, 391-422.

Pombal, M. A., Rodicio, M. C., and Anadón, R. (1994). Development and organization of the ocular motor nuclei in the larval sea lamprey, Petromyzon marinusL.: an HRP study. J. Comp. Neurol. 341, 393-406.

Puelles, L., Kuwana, E., Puelles, E., Bulfone, A., Shimamura, K., Keleher, J., Smiga, S., and Rubenstein, J. L. (2000). Pallial and subpallial derivatives in the embryonic chick and mouse telencephalon, traced by the expression of the genes Dlx-2, Emx-1, Nkx-2.1, Pax-6, and Tbr-1. J. Comp. Neurol. 424, 409-438.

Ren, X., Chang, S., Laframboise, A., Green, W., Dubuc, R., and Zielinski, B.
(2009). Projections from the accessory olfactory organ into the medial region of the olfactory bulb in the sea lamprey (Petromyzon marinus): a novel vertebrate sensory structure? J. Comp. Neurol. 516, 105-116.

Richardson, M. K., Admiraal, J., and Wright, G. M. (2010). Developmental anatomy of lampreys. Biol. Rev. Camb. Philos. Soc. 85, 1-33.

Richardson, M. K., and Wright, G. M. (2003). Developmental transformations in a normal series of embryos of the sea lamprey Petromyzon marinus (Linnaeus). J. Morphol. 257, 348-363.

Robertson, B., Auclair, F., Ménard, A., Grillner, S., and Dubuc, R. (2007). GABA distribution in lamprey is phylogenetically conserved. J. Comp. Neurol. 503, 47-63.

Robertson, B., Saitoh, K., Ménard, A., and Grillner, S. (2006). Afferents of the lamprey optic tectum with special reference to the GABA input: combined tracing and immunohistochemical study. J. Comp. Neurol. 499, 106-119.

Rodicio, M. C., Pombal, M. A., and Anadón, R. (1995). Early development and organization of the retinopetal system in the larval sea lamprey, Petromyzon marinus L. An HRP study. Anat. Embryol. (Berl.) 192, 517-526.

Rodríguez-Muñoz, R., Nicieza, A., and Braña, F. (2001). Effects of temperature on developmental performance, survival and growth of sea lamprey embryos. J. Fish. Biol. 58, 475-486.

Ronan, M., and Northcutt, R. G. (1998). "The central nervous system of hagfishes," in The Biology of Hagfishes, eds J. M. Jorgensen, J. P. Lomholt, R. E. Weber, and H. Malte (London: Chapman \& Hall), 452-479.

Rovainen,C.M.(1982)."Neurophysiology," in The Biology of Lampreys, Vol. 4, eds M. W. Hardisty and I. C. Potter (London: Academic Press), 1-136.

Rubin, A. N., Alfonsi, F., Humphreys, M.P., Choi, C. K. P., Rocha, S. F., and Kessaris, N. (2010). The germinal zones of the basal ganglia but not the septum generate GABAergic interneurons for the cortex. J. Neurosci. 30, 12050-12062.

Rubinson, K. (1990). The developing visual system and metamorphosis in the lamprey. J. Neurobiol. 21, 1123-1135.

Ruiz, Y., Pombal, M. A., and Megías, M. (2004). Development of GABAimmunoreactive cells in the spinal cord of the sea lamprey, P. marinus. J. Comp. Neurol. 470, 151-163.

Schnitzlein, H. N. (1982). "Cyclostomes," in Comparative Correlative Neuroanatomy of the Vertebrate Telencephalon, eds E. C. Crosby and $\mathrm{H}$. N. Schnitzlein (New York: Macmillan Press), 4-26.

Schöber, W. (1964). Vergleichendanatomische Untersuchungen am
Gehirn der Larven und adulten Tiere von Lampetra fluvialis (Linné, 1758) und Lampetra planeri (Bloch, 1984) J. Hirnforsch. 7, 107-209.

Schultze, M.S. (1856). Die EntwickelungsGeschichte von Petromyzon planeri. Harlem: Loosjes.

Scott, W. B. (1887). Notes on the development of Petromyzon. J. Morphol. $1,253-310$.

Shipley, A. E. (1887). On some points in the development of Petromyzon fluviatilis. Q. J. Microsc. Sci. 27, 325-370.

Sterzi, G. (1907). Il Sistema Nervoso Centrale dei Vertebrati. Ricerche Anatomiche ed Embriologiche, Vol. 1. Ciclostomi. Padova: Angelo Draghi.

Tahara, Y. (1988). Normal stages of development in the lamprey, Lampetra reissneri (Dybowski).Zool. Sci. 5, 109-118.

Tobet, S. A., Chickering, T. W., King, J. C., Stopa, E. G., Kim, K., Kuo-Leblank, V., and Schwarting, G. A. (1996). Expression of gamma-aminobutyric acid and gonadotropin-releasing hormone during neuronal migration through the olfactory system. Endocrinology 137, 5415-5420.

Uchida, K., Murakami, Y., Kuraku, S. Hirano, S., and Kuratani, S. (2003). Development of the adenohypophysis in the lamprey: evolution of epigenetic patterning programs in organogenesis. J.Exp.Zool. B Mol. Dev. Evol.300,32-47.

VanDenbossche, J., Seelye, J. G., and Zielinski, B. S. (1995). The morphology of the olfactory epithelium in larval, juvenile and upstream migrant stages of the sea lamprey, Petromyzon marinus. Brain Behav. Evol. 45, 19-24.

Vidal-Pizarro, I., Swain, G. P., and Selzer, M. E. (2004). Cell proliferation in the lamprey central nervous system. $J$. Comp. Neurol. 469, 298-310.

Villar-Cerviño, V., Barreiro-Iglesias, A. Anadón, R., and Rodicio, M. C. (2009). Development of glycine immunoreactivity in the brain of the sea lamprey: comparison with gammaaminobutyric acid immunoreactivity. J. Comp. Neurol. 512, 747-767.

Villar-Cerviño, V., Holstein, G. R., Martinelli, G. P., Anadón, R., and Rodicio, M. C. (2008). Glycineimmunoreactive neurons in the developing spinal cord of the sea lamprey: comparison with the gammaaminobutyric acidergic system. $J$. Comp. Neurol. 508, 112-130.

Villar-Cheda, B., Pérez-Costas, E., Meléndez-Ferro, M., Abalo, X. M., Rodríguez-Muñoz, R.,Anadón, R., and Rodicio, M. C. (2002). Proliferating cell nuclear antigen (PCNA) immunoreactivity and development of the pineal complex and habenula of the sea lamprey. Brain Res. Bull. 57, 285-287.

Villar-Cheda, B., Pérez-Costas, E., Meléndez-Ferro, M., Abalo, X. M.,
Rodríguez-Muñoz, R., Anadón, R., and Rodicio, M. C. (2006). Cell proliferation in the forebrain and midbrain of the sea lamprey. J. Comp. Neurol. 494, 986-1006.

von Kupffer, K. (1906). “Die Morphogenie des Centralnervensystems," in Handbuch der Vergleichenden und Experimentellen Entwicklungslehre der Wirbeltiere, Vol. 2, Part III, ed. O. Hertwig (Jena: Fisher), 1-272.

Watanabe, A., Hirano, S., and Murakami, Y. (2008). Development of the lamprey central nervous system, with reference to vertebrate evolution. Zool. Sci. 25, 1020-1027.

Weigle, C., and Northcutt, R. G. (1999). The chemoarchitecture of the forebrain of lampreys: evolutionary implications by comparisons with gnathostomes. Eur. J. Morphol. 37, 122-125.

Wicht, H., and Nieuwenhuys, R. (1998). "Hagfishes (Myxinoidea)," in The Central Nervous System of Vertebrates, Vol. 1, eds R. Nieuwenhuys, H. J. ten Donkelaar, and C. Nicholson. (Berlin: Springer-Verlag), 497-549.

Yáñez, J., and Anadón, R. (1994). Afferent and efferent connections of the habenula in the larval sea lamprey (Petromyzon marinus L.): an experimental study. J. Comp. Neurol. 345, 148-160.

Zielinski, B. S., Fredricks, K., McDonald, R., and Zaidi, A. U. (2005) Morphological and electrophysiological examination of olfactory sensory neurons during the early developmental prolarval stage of the sea lamprey Petromyzon marinus L. J. Neurocytol. 34, 209-216.

Conflict of Interest Statement: The authors declare that the research was conducted in the absence of any commercial or financial relationships that could be construed as a potential conflict of interest.

Received:30 December 2010; paperpending published: 12 January 2011; accepted: 07 March 2011; published online: 18 March 2011.

Citation: Pombal MA, Álvarez-Otero R, Pérez-Fernández J, Solveira C and Megías M (2011) Development and organization of the lamprey telencephalon with special reference to the GABAergic system. Front. Neuroanat. 5:20. doi: 10.3389/ fnana.2011.00020

Copyright $\odot 2011$ Pombal, Álvarez-Otero, Pérez-Fernández, Solveira and Megías. This is an open-access article subject to an exclusive license agreement between the authors and Frontiers Media SA, which permits unrestricted use, distribution, and reproduction in any medium, provided the original authors and source are credited. 